\title{
Time to Move to Targeted Drugs in Biliary Tract Cancer?
}

\author{
Christophe Louvet ${ }^{\text {a.b }}$ Christophe Tournigand ${ }^{\mathrm{a}}$ \\ a Service d'oncologie, hôpital St-Antoine, \\ ${ }^{\mathrm{b}}$ Université Pierre et Marie Curie (Paris VI), Paris, France
}

Biliary tract cancers comprise a large variety of anatomic situations: intrahepatic cholangiocarcinomas, extrahepatic cholangiocarcinomas, adenocarcinomas of the gallbladder and of ampulla of Vater. Even if they have different prognoses, and require different surgical procedures when resectable, they are often together considered in clinical trials of chemotherapy for advanced disease. Unfortunately, the majority of patients presents with unresectable disease at diagnosis, and overall prognosis remains very poor.

The use of chemotherapy in advanced biliary cancers (ABC) was justified by the Glimelius study [1], where palliative chemotherapy demonstrated a survival and a quality of life advantage as compared to best supportive care. Quality of biliary drainage remains a key prognostic factor, and must be the first goal to achieve before starting chemotherapy. Until recently, $\mathrm{ABC}$ were considered as orphan diseases, and a lot of small non randomized studies based on various drugs and combined treatments have been published. A review of the literature (112 trial arms and 2,810 patients) confirmed the value of several national guidelines: single-agent antimetabolites (gemcitabine or 5 fluorouracil) are more active than any other single drugs, and combined treatments of antimetabolite + platinum salt are more active than single agents or any other combined treatment [2], the more promising combinations being gemcitabine + cisplatin and gemcitabine + oxaliplatin $[3,4]$. This was later confirmed this year by one Japanese randomized phase II study [5] and especially by one UK randomized phase III study [6], which found a significant advantage in terms of overall survival for this combination compared to gemcitabine alone. This UK study not only defined a new standard of care, but also demonstrated that it is now feasible to perform large-scale studies in ABC.

Targeted therapies are now widely used in oncology, and definitively represent a new step in the therapeutic advances. Despite the definition of a new standard of care in $\mathrm{ABC}$, prognosis remains very poor with a median survival of less than a year, and this warrants to test targeted therapies in this disease. To date, no consistent data concerning ABC and antiangiogenic drugs is available, and very few concerning $\mathrm{ABC}$ and anti EGFR (epidermal growth factor receptor) drugs. In this issue of Onkologie, Chang and collaborators [7] report 5 cases of patients with $\mathrm{ABC}$ and treated with cetuximab combined with modulated fluorouracil, either as first- or as second-line treatment. All 5 patients showed disease control (1 CR, 3 PR and 1 SD). Activity of anti EGFR in ABC was previously reported in two cases (PR achieved in first line using gemcitabine + cetuximab [8]; PR achieved in first line using radiation therapy combined with cetuximab [9]), and in a series of 9 patients resistant to gemcitabine + oxaliplatin (1 CR, 1 PR and 1 SD out of the 9 patients) after addition of cetuximab to GEMOX at progression [10]. Results of a prospective phase II study using GEMOX + cetuximab as firstline treatment for $30 \mathrm{ABC}$ patients were reported during the past ASCO 2009, with an impressive 63.3\% response rate and a 12.7 months median survival [11]. At the same time, preliminary results of a French-German randomized study (GEMOX with or without cetuximab) have been reported, with a promising increase in progression-free survival (PFS) for the combined arm [12].

It is now well demonstrated that efficacy of EGFR antibodies is related to tumoral K-RAS wild-type status and not to EGFR expression in colon cancer [13]. Therefore, EGFR antibodies should be restricted to a sub-population of patients. This may not be the case in other types of tumor, and relationships between EGFR antibodies activity and K-RAS mutational status have to be further explored. EGFR overexpression is strongly correlated with tumor progression in $\mathrm{ABC}$ [14]. K-RAS tumor mutations have been reported in $\mathrm{ABC}$, at various rates depending on the geographic origin of the patients as well as on the primary tumor location: reported mu-

\section{KARGER}

Fax +497614520714

Information@Karger.de

www.karger.com (c) 2010 S. Karger GmbH, Freiburg

Accessible online at:

www.karger.com/onk
Dr. Christophe Louvet

Service d'oncologie, hôpital St-Antoine,

184 rue du faubourg St-Antoine, 75012, Paris, France

Tel. +3314928 23-45, Fax -44

christophe.louvet@sat.aphp.fr 
tations rate ranged from 0 to $50 \%$ in Asian patients $[15,16]$ and from 12 to $54 \%$ in patients from western countries [11, 17]; in gallbladder, ampulloma and extrahepatic cholangiocarcinomas, such mutations seem to be absent or very infrequent [18]. Considering the poor prognosis of gallbladder cancers treated with conventional chemotherapy, these findings are to be taken into account. Interestingly, neither progression-free survival nor overall survival were affected by K-RAS status in the GEMOX + cetuximab phase II study [11].
Regarding the poor prognosis of $\mathrm{ABC}$ despite the recent definition of a standard of care, improvements of results are urgently needed. Antiangiogenic drugs deserve to be tested. The use of EGFR inhibitors appears as a promising option. However, this should be done through well conducted prospective clinical trials, with companion biological explorations, in order to better understand the optimal place of such drugs in $\mathrm{ABC}$.

\section{References}

1 Glimelius B, Hoffman K, Sjödén PO, Jacobsson G, Sellström H, Enander LK, Linné T, Svensson C: Chemotherapy improves survival and quality of life in advanced pancreatic and biliary cancer. Ann Oncol 1996;7:593-600.

2 Eckel F, Schmid RM: Chemotherapy in advanced biliary tract adenocarcinoma: a pooled analysis of clinical trials. Br J Cancer 2007;96:896-902.

- 3 Valle JW, Wasan H, Johnson P, Jones E, Dixon L, Swindell R, Baka S, Maraveyas A, Corrie P, Falk S, Gollins S, Lofts F, Evans L, Meyer T, Anthoney A, Iveson T, Highley M, Osborne R, Bridgewater J: Gemcitabine alone or in combination with cisplatin in patients with advanced or metastatic cholangiocarcinomas or other biliary tract tumors: a multicenter randomised phase II study - the UK ABC01 study. Br J Cancer 2009;101:621-627.

4 André T, Reyes-Vidal JM, Fartoux L, Ross P, Leslie M, Rosmorduc O, Clemens MR, Louvet $\mathrm{C}$ Perez N, Mehmud F, Scheithauer W: Gemcitabine and oxaliplatin in advanced biliary tract carcinoma: a phase II study. Br J Cancer 2008;99:862-867.

5 Furuse J, Okusaka T, Miyazaki M, Taniai H, Nimura Y: A randomized study of gemcitabine/cisplatin versus single-agent gemcitabine in patients with biliary tract cancer. Proc Am Soc Clin Oncol 2009;221s, abstr 4579.

6 Valle JW, Wasan HS, Palmer DD, Cunningham D, Anthoney DA, Maraveyas A, Hughes SK Roughton M, Bridgewater JA: Gemcitabine with or without cisplatin in patients with advanced or metastatic biliary tract cancer: results of a multicenter, randomized phase III trial (the UK ABC-02 trial). Proc Am Soc Clin Oncol 2009;202s, abstr 4503.
7 Chang PY, Cheng MF, Lee HS, Hsieh CB, Yao NS: Preliminary experience of cetuximab in the treatment of advanced-stage biliary tract cancer. Onkologie 2010;33: DOI: 10.1159/000264613.

8 Sprinzl MF, Schimanski CC, Moelher M, Schadmand-Fischer S, Galle PR, Kanzler S: Gemcitabine in combination with EGF-Receptor antibody (cetuximab) as a treatment of cholangiocarcinoma: a case report. BMC Cancer 2006;6:190.

9 Huang TW, Wang CH, Hsieh CB: Effects of the anti-epidermal growth factor receptor antibody cetuximab on cholangiocarcinoma of the liver. Onkologie 2007;30:129-131.

10 Paule B, Herelle MO, Rage E, Ducreux M, Adam R, Guettier C, Bralet MP: Cetuximab plus gemcitabine-oxaliplatin (GEMOX) in patients with refractory advanced intrahepatic choloangiocarcinomas. Oncology 2007:72:105-110.

11 Gruenberger B, Schueller J, Tamandl D, Kaczirek K, Schernthaner G, Gruenberger T: K-RAS status and response in patients with advanced or metastatic cholangiocarcinoma treated with cetuximab plus gemcitabine-oxaliplatin (GEMOX): a single center phase II study. Proc Am Soc Clin Oncol 2009;223s, abstr 4586

12 Malka D, Trarbach T, Fartoux L, Mendiboure J, de la Fouchardière C, Viret F, Assenat F, Boucher E, Rosmorduc O, Greten T: A multicenter, randomized phase II trial of gemcitabine and oxaliplatin (GEMOX) alone or in combination with biweekly cetuximab in the first-line treatment of advanced biliary cancer: interim analysis of the BINGO trial. Proc Am Soc Clin Oncol 2009;206s: abstr 4520.
13 Lievre A, Bachet JB, Le Corre D, Boige V, Landi B, Emile JF, Côté JF, Tomasic G, Penna C, Ducreux M, Rougier P, Penault-Llorca F, LaurentPuig P: KRAS mutation status is predictive of response to cetuximab therapy in colorectal cancer. Cancer Res 2006;66:3992-3995.

14 Yoshikawa D, Ojima H, Iwasaki M, Hiraoka N, Kosuge T, Kasai S, Hirohashi S, Shibata T: Clinicopathological and prognostic significance or EGFR, VEGF, and HER2 expression in cholangiocarcinoma. Br J Cancer 2008;98:418-425.

15 Petmitr S, Pinlaor S, Thousungnoen A, Karalak A, Migasena P: K-RAS oncogene and $\mathrm{p} 53$ gene mutations in cholangiocarcinoma from Thai patients. Southeast Asian J Trop Med Public Health 1998; 29:71-75.

16 Kiba T, Tsuda H, Pairojkul C, Inoue S, Sugimura T, Hirohashi S: Mutations of the p53 tumor suppressor gene and the ras gene family in intrahepatic cholangiocellular carcinomas in Japan and Thailand. Mol Carcinog 1993;8:312-318.

17 Tannapfel A, Benicke M, Katalinic A, Uhlmann D, Köckerling F, Hauss J, Wittekind C: Frequency of p16(INK4A) alterations and K-ras mutations in intrahepatic cholangiocarcinoma of the liver. Gut 2000;47:721-727.

18 Lee JC, Lin PW, Lin YJ, Lai J, Yang HB, Lai MD: Analysis of K-ras gene mutations in periampullary cancers, gallbladder cancers and cholangiocarcinomas from paraffin-embedded tissue sections. J Formos Med Assoc 1995;94:719-723. 